\title{
TAKING WORKERS' RIGHTS SERIOUSLY: PRIVATE PROSECUTIONS OF EMPLOYMENT STANDARDS VIOLATIONS
}

\section{Kent Elson*}

This paper examines private prosecutions as a tool to challenge the state's inadequate enforcement of employment standards. In Ontario, poor enforcement of employment standards means that there are no costs for non-compliance, that orders to pay wages are typically not fully paid and that vulnerable workers are left unprotected. Private prosecutions are one tool that could be used by private actors to fight these problems. Historically, private prosecutions have been used where there is a gap in government enforcement, most recently to bring environmental offenders to justice. Privately prosecuting employment standards violations would continue that tradition and would promote compliance through the stigma of criminal proceedings, and by conveying the message that employment standards violations are crimes. This paper discusses the gaps in the enforcement of employment standards in Ontario (section II), explains how private prosecutions can help and how this fits with the historic use of private prosecutions (section III), and describes how private prosecutions of employment standards could be easily implemented (section IV).

Cet article examine la question de poursuites privées comme outil pour contester la mise en application inadéquate des normes d'emploi par l'état. En Ontario, les faiblesses dans la mise en application des normes d'emploi font que leur inobservation n'entraîne aucuns coûts, que, typiquement, les ordonnances de payer des gages ne sont pas totalement observées et que les travailleurs vulnérables demeurent sans protection. Les poursuites privées sont un outil que pourraient utiliser des acteurs privés pour combattre ces problèmes. Historiquement, on a utilisé les poursuites privées où il y a lacune dans la mise en application de lois par le gouvernement, le plus récemment pour traduire en justice les contrevenants par rapport à l'environnement. Les poursuites privées en cas d'infractions contre les normes d'emploi continueraient cette tradition et favoriseraient l'observation des lois par la stigmatisation associée aux instances criminelles et en communiquant le message que les infractions contre les normes d'emploi sont des crimes. Cet article discute les lacunes dans la mise en application des normes d'emploi en Ontario (section II), explique la façon dont les poursuites privées peuvent aider et comment cela cadre avec leur utilisation historique (section III), et décrit comment on pourrait facilement mettre en pratique les poursuites privées pour infractions des normes d'emploi (section IV).

\footnotetext{
Of Klippensteins Barristers and Solicitors; LL.B., Osgoode Hall Law School. Many, many thanks to Elisabeth Bruckmann, Mary Gellatly, Chantal Morton, Deena Ladd, Karen Dick and Lake Ontario Waterkeeper. Any errors or misjudgements are my own.
}

(2008) 26 Windsor Y.B. Access Just. 
Work is one of the most fundamental aspects in a person's life, providing the individual with a means of financial support and, as importantly, a contributory role in society. A person's employment is an essential component of his or her sense of identity, self-worth and emotional well-being.

Supreme Court of Canada, Chief Justice Dickson ${ }^{1}$

\section{INTRODUCTION}

Work is an essential and fundamentally important part of an individual's life. It provides the economic means of sustaining a stable lifestyle and plays a central role in defining a person's identity, dignity and self-worth. A steady income is strongly correlated with good health, education and well-being. Because work is so essential to the individual, the regulation of work is a defining feature of a society. David Beatty notes "that it is in their regulation of their most central relationships, like employment, that societies stake out the clearest expression of their social and economic characters." "If our society is concerned about fairness and human dignity then it should take workers' rights seriously.

This essay describes one instance where work is not taken seriously and suggests that civil society should take strong actions to remedy this. In Ontario, the Employment Standards Act, 2000 [ESA] holds employers to minimum standards such as the payment of wages, minimum wages, overtime and vacation pay. Unfortunately, the Ministry of Labour [Ministry] does not treat violations of these minimum employment standards as crimes even in light of their prevalence and catastrophic social effects. The vast majority of unpaid workers are denied access to criminal justice because their delinquent employers are never charged by the Ministry. I suggest that civil society should fill this gap in enforcement by prosecuting privately. ${ }^{4}$ This paper discusses the employment standards enforcement gap in Ontario (section II), explains how, in keeping with their historically democratic role, private prosecutions can help fill this enforcement gap (section III) and describes how private prosecutions of employment standards could be easily implemented (section IV).

\section{GAPS IN ONTARIO'S EMPLOYMENT STANDARDS REGIME}

The protection of workers' rights requires both strong laws and adequate enforcement. Many problems require legislative amendment, such as the increasing number of workers who are de facto unprotected by the ESA because

1 Reference Re Public Service Employee Relations Act (Alberta), [1987] 1 S.C.R. 313, [1987] 78 A.R. 1 at para. 91.

2 David Beatty, "Labour is not a Commodity" in Bernard Adell et al., eds., Labour \& Employment Law, 7th ed. (Toronto: Irwin Law, 2004) 4 at 4.

3 S.O. 2000, c. 41 [ESA].

4 This idea has been informally discussed in the workers' rights division of Parkdale Community Legal Services, and was briefly discussed in a paper by a student legal worker (Scott Bergman) at that clinic. However, I have not found an in-depth examination of this tool in the employment standards context. 
their employers categorize them as independent contractors. ${ }^{5}$ This paper does not canvass all of the promising legislative proposals to improve employment standards coverage and compliance in Ontario and Canada. ${ }^{6}$ Rather, this paper focuses on two problems - that there are no costs for breaking the law and thus no deterrence, and that orders to pay wages are usually not fully paid - and looks at a solution that can be implemented by private actors under the existing legislative framework: private prosecutions.

\section{A. Deterrence: No Costs or Punishment for Violating The Law}

The majority of the ESA is concerned with payments that must be made by employers. The most basic but often violated standard is that employers must pay their employees their wages. ${ }^{7}$ If an employer fails to pay, the employee may (but often does not) make a formal complaint to the Ministry. The file will eventually be assigned to an Employment Standards Officer [Officer] who will investigate the complaint.

If the Officer finds that wages are due, they will either informally ask the employer to pay the employee or issue an "order to pay wages." 8 The employer may be required to pay a $10 \%$ "administrative fee," but only if it is necessary to issue an order. ' These orders are merely restitution because they only force the employer to pay what was already owed - they do not impose any penalty on the employer. Furthermore, employment standards claims are usually settled for less than what the employer owed the employee in the first place. ${ }^{10}$ The Auditor General of Ontario recognises that " $[\mathrm{t}]$ his lack of any punitive action ... could encourage some employers to ignore their legal obligations to employees." 11

Regulatory compliance is in part a function of the potential offender's likely gain from non-compliance, the probability of getting caught and the severity of punishment. ${ }^{12}$ This is based on the reasonable assumption that more people will break the law as the benefits of non-compliance increase and the risks de-

5 Juana Berinstein \& Mary Gellatly, Effective and Enforced Employment Standards for Improved Income Security (2005), online: Workers' Action Centre <http://www.workersactioncentre.org/ documents/Effective\%20and\%20Enforced\%20Employment\%20Standards.pdf> [WAC 2005].

6 See e.g. Ibid. at 5; Working on the Edge (2007), online: Workers' Action Centre <http://www. workersactioncentre.org/WAC\%20Report\%202007.pdf> at 56 [WAC 2007]; Roy J. Adams, "Employment Standards in Ontario: An Industrial Relations Systems Analysis" (1987) 42:1 R.I. 46 at 59; Harry Arthurs, Fairness at Work: Federal Labour Standards for the 21st Century, Final Report of the Federal Labour Standards Review (Gatineau, Quebec: Human Resources and Social Development Canada, 2006).

7 ESA, supra note 3, s. 11.

$8 \quad$ Ibid., s. 103.

9 Ibid., s. 103 (2)

10 WAC 2007, supra note 6 at 56-7; see also footnote 32.

112004 Report of the Auditor General of Ontario, online: Auditor General of Ontario <http://www. auditor.on.ca/en/reports_2004_en.htm> at 240 [Auditor General 2004].

12 A. Mitchell Polinsky and Steven Shavell, "The Optimal Use of Fines and Imprisonment" (1984) 24 Journal of Public Economics 89 at 91; Gary S. Becker, "Crime and Punishment: An Economic Approach" (1968) 76:2 Journal of Political Economy 169 at 176 (although other considerations may also be important, most scholars agree that punishment and the likelihood of getting punished are key factors in ensuring regulatory compliance). 
crease. ${ }^{13}$ The likelihood of getting caught for an ESA violation is small because of insufficient Ministry investigations and because the majority of workers do not complain when their rights are violated, often in fear of retribution. ${ }^{14}$ The ESA creates a perverse incentive structure: the potential gain from non-compliance is large and in most cases there is no punishment, even where the employer gets caught. ${ }^{15}$ With the low levels of investigations and employee reluctance to make a complaint (low detection), the slow investigation process and the meagre penalties (low punishment), unscrupulous employers will likely decide that violating the ESA is the easiest and cheapest option (low compliance). ${ }^{16}$ Unfortunately, the laws in other provinces and at the federal level suffer from a similar lack of penalties and irrational incentive structures. ${ }^{17}$

In 2004 the Ontario Government gave Employment Standards Officers the power to issue tickets for violations of employment standards. ${ }^{18}$ Although this is a significant step, tickets are not a sufficient deterrent. In 2005, the Ministry found employer violations in over 11,000 claims, while the number of violations including unreported contraventions would have been far higher. ${ }^{19}$ In that year just over 300 tickets were issued. ${ }^{20}$ This small number of tickets, each for a few hundred dollars, cannot be expected to deter an employer who saves far more every week - or even every day - by violating minimum employment standards. Furthermore, these tickets are issued under Part I of the Provincial Offences Act $[\mathrm{POA}] .{ }^{21}$ This is the same part of the POA used for matters such as traffic and speeding tickets. These tickets do not reflect the seriousness of employment standards contraventions. Like drivers who exceed the speed limit, many employers will continue to violate the law and hope that they will not get caught.

Tickets are an appropriate means to counter less serious offences. ${ }^{22}$ However,

13 Becker, ibid. at 176. See also footnote 89 and accompanying text.

14 WAC 2007, supra note 6 at 51-56; Auditor General 2004, supra note 11 at 242 (90\% of complaints were filed by individuals no longer working for the employers against which they filed claims).

15 See WAC 2005, supra note 5; WAC 2007, supra note 6.

16 See Auditor General 2004, supra note 11; WAC 2005, supra note 5 (re gaps in the ESA).

17 Patrice Dutil and Ron Saunders, New Approaches in Achieving Compliance with Statutory Employment Standards (Ottawa: Canadian Policy Research Networks and The Institute of Public Administration of Canada, 2005) at 18, 24; David B. Fairey, "New 'Flexible' Employment Standards Regulation in British Columbia" (2007) 21 J.L. \& Soc. Pol'y 91 (the situation is arguably even worse in British Columbia where recently created barriers restrict the number of claims made by employees); see also Arthurs, supra note 6 at 222 .

18 Ontario Ministry of Labour, Press Release, "McGuinty Government Steps up Employment Standards Enforcement" (14 July 2004), online: Ontario Ministry of Labour <http://www. labour.gov.on.ca/english/news/2004/04-81.html>; O.Reg. 162/04 s. 1 (amending the POA to implement the ticketing provisions of the $E S A)$.

19 WAC 2007, supra note 6 at 59; Adams, supra note 6 (Few employees complain to the Ministry, with most complaints occurring when the employee leaves the workplace. Therefore it is clear that the actual number of violations is far greater than the violations uncovered by employee claims.).

20 Enforcement Activities: Prosecution and Conviction Statistics, online: Ontario Ministry of Labour $<$ http://www.labour.gov.on.ca/english/es/report_card/rc_2.html>.

21 R.S.O. 1990 , c. P.33 [POA].

222006 Report of the Auditor General of Ontario, online: Auditor General of Ontario <http://www. auditor.on.ca/en/reports_2006_en.htm > at 310 [Auditor General 2006]. 
the ESA has another mechanism to punish the more serious offences - prosecutions. It is an "offence" to contravene any part of the ESA or any regulation under the ESA. ${ }^{23}$ Every time an Employment Standards Officer issues an order to pay they have determined that the employer has violated the ESA, and therefore an offence has been committed. However, the offender has not yet been prosecuted. They have merely been ordered to stop breaking the law or ordered to pay what they already owed. Between 1999 and 2004, the Ministry substantiated violations (i.e. offences) in 51,000 claims and only sent eighteen cases for prosecution; that is an average of fewer than four per year. ${ }^{24}$ This chronic problem has long been recognised. ${ }^{25}$ It is also not limited to Ontario, and in the federal jurisdiction no employer has been convicted for a violation of employment standards since 1987. ${ }^{26}$ The Ontario Ministry has responded with some improvements and with somewhat deceptive statistics. ${ }^{27}$ The lack of Ministry prosecutions means that there are no costs for violating the ESA, few incentives to pay when initially requested, and little deterrence to dissuade employers from future violations.

\section{B. Enforcement: Endemic Non-compliance with Ministry Orders}

Even after an employer has been ordered to pay, the Ministry usually fails to collect the full amount of the unpaid wages. Only the Ministry, not the employee, has the power to enforce orders issued under the ESA by an Employment Standards Officer. ${ }^{28}$ This is done by filing the orders in court, which can then be enforced in the same manner as a judgement of that court. ${ }^{29}$ Today, most orders are sent to a private collections agency that has delegated powers to enforce the orders. ${ }^{30}$

Although many employers voluntarily pay when the Ministry initially determines that wages are owing, most employers cannot be forced to pay if they refuse. ${ }^{31}$ Of the overdue orders sent to collection agencies between 2000 and 2003,

23 ESA, supra note 3, s. 132.

24 Auditor General 2004, supra note 11 at 244.

25 Ibid. (this 2004 audit notes "no significant improvement" since the last audit in 1991); Adams, supra note 6 at 55; WAC 2007, supra note 6 at 59; Judy Fudge, "Reconceiving Employment Standards Legislation: Labour Law's Little Sister and the Feminization of Labour" (1991) 7 J.L. \& Soc. Pol'y 73 at 84; Mark Thomas, Regulating Flexibility: The Ontario Employment Standards Act and the Politics of Flexible Production (Ph.D. Thesis, York University, Faculty of Graduate Studies, 2003) [unpublished] at 325.

26 Arthurs, supra note 6 at 220.

27 Dutil and Saunders, supra note 17 at 18 (regarding Ontario prosecutions in mid-2005, the authors state: "Since July $2004 \ldots$ there have been over 220 prosecutions commenced, compared to only 18 prosecutions in the past five years."); Ministry of Labour, supra note 20 (claiming that 226 "prosecutions" were initiated in 2004 and 318 in 2005); These statistics deceptively group prosecutions of offences with tickets (see footnote 18 and accompanying text). Most people would not say that they have been "prosecuted" when they receive what is equivalent in severity to a traffic ticket. According to Ministry statistics provided to the author, there were an average of nine files with convictions per year between 2004 and 2007.

28 ESA, supra note 3, s. 103 (b)

29 Ibid.s. 126-127.

30 Auditor General 2006, supra note 22 at 311.

31 Auditor General 2004, supra note 11 at 246 ("in about $40 \%$ of complaints the employer voluntarily pays without the need for further collection efforts"); However, voluntary payments 
less than $16 \%$ of the money owed was collected. ${ }^{32}$ This means that in roughly $85 \%$ of the cases where the orders were initially disregarded, the employer managed to profit from its violation of the ESA. As just described, barely any of these employers were prosecuted, and therefore they completely avoided any punishment. The federal jurisdiction suffers from the same problem, as described by Harry Arthurs: "[ $t]$ he more recalcitrant the employer's stance, the less chance there is for recovery." ${ }^{33}$ When the Ministry fails to collect overdue wages after an order has been made and then fails to prosecute, employers are presumably emboldened to offend again. Employees are left vulnerable, powerless, unprotected and without access to justice. Both employers and employees are sent the message that society does not take workers' rights seriously.

\section{The Human and Social Costs of Violations of Employment Standards}

The non-payment of wages is deeply damaging to our social fabric. In a typical ESA violation, employees are unpaid for a few weeks and then fired without termination pay. ${ }^{34}$ This can cause a spiral into acute and sometimes chronic poverty. Low-paid workers are left unable to pay their rent and psychologically vulnerable. ${ }^{35}$ As noted by the Supreme Court of Canada:

The point at which the employment relationship ruptures is the time when the employee is most vulnerable and hence, most in need of protection. In recognition of this need, the law ought to encourage conduct that minimizes the damage and dislocation (both economic and personal) that result from dismissal. ${ }^{36}$

Workers who suffer the consequences of employment standards violations are often vulnerable to begin with, and because of this initial precarious position, have difficulty getting back on their feet again. ${ }^{37}$

These observations are supported by statistics. In a 2005 report, Statistics Canada found that loss of work has the largest impact on entry into poverty of all studied variables. ${ }^{38}$ Although this comes as no surprise, it does not have to

include cases where the employee agrees to receive less than what was owed. Unfortunately, the Ministry does not maintain statistics on the percent of voluntary payments that are made in full compared to the percent that are settled for less. Although such agreements are unfair to the worker who is not being paid his or her wages, employees often settle to get cash in hand, to avoid the costs, effort and delay of a hearing and to hedge against the likelihood that collections will fail.

32 Auditor General 2004, supra note 11 at 246.

33 Supra note 6 at 214.

34 See e.g. WAC 2007, supra note 6 at 48.

$35 \mathrm{Ibid}$. at 36 (detailing the stress caused by precarious work).

36 Wallace v. United Grain Growers Ltd., [1997] 3 S.C.R. 701, 152 D.L.R. (4th) 1 at para. 95.

37 Arthurs, supra note 6 at 230 - 232 (detailing the plight of vulnerable workers).

38 The Ins and Outs of Poverty in Advanced Economies: Poverty Dynamics in Canada, Germany, Great Britain, and the United States (Jan 2005), online: Statistics Canada < http://www.statcan. $\mathrm{gc.ca} / \mathrm{pub} / 75 \mathrm{f} 0002 \mathrm{~m} / 75 \mathrm{f} 0002 \mathrm{~m} 2005001$-eng.pdf $>$ at 17 (although divorce is more likely to cause poverty among family members, the overall impact is less as it occurs less frequently than job losses). 
be this way. Losing your job should not entail falling into transitory let alone chronic poverty. The Statistics Canada report also found that Great Britain and Germany are better able to reduce the harmful effects of job loss: the loss of fulltime work in Canada is more connected to chronic poverty when compared to those countries. ${ }^{39}$ Employment standards are meant to protect vulnerable workers in general and to provide a cushion in the event of job loss. ${ }^{40}$ We could be doing a better job protecting vulnerable workers by improving the enforcement of minimum employment standards.

The negative effects of employment standards non-compliance are not felt evenly across Canadian society. ${ }^{41}$ Women are more likely to work in vulnerable employment sectors. ${ }^{42}$ Similarly, recent immigrants and members of families with no potential second adult wage earner are disproportionately employed in the most precarious employment situations. ${ }^{43}$ Unfortunately, these disparities in vulnerability are only increasing. ${ }^{44}$ Because employment standards violations are more common in marginal employment sectors and because these workers are more vulnerable to bad employers, the costs of not enforcing employment standards are disproportionately borne by women, recent immigrants, and other distinct groups of vulnerable workers. ${ }^{45}$

Certain acts are made crimes, punishable by penal sanctions, because they cause injury to the general public. ${ }^{46}$ Criminal laws are enacted with a view to a public purpose, such as public peace, morality, or health. ${ }^{47}$ Whether employment standards violations are best described as crimes or as public welfare offences, the important point is that they should be punished by the state, with the attendant penalties and moral sanctions. ${ }^{48}$ Many employment standards violations, such as the flagrant non-payment of wages, should be treated like other crimes and

39 Ibid. at 18.

40 Arthurs, supra note 6 at 230.

41 Cynthia J. Cranford \& Leah F. Vosko, "Conceptualizing Precarious Employment: Mapping Wage Work across Social Location and Occupational Context" in Leah F. Vosko ed., Precarious Employment (Montreal: McGill-Queen's University Press, 2006) 43; Tania Das Gupta, "Racism/ Anti-Racism, Precarious Employment, and Unions" in Leah F. Vosko ed., Precarious Employment (Montreal: McGill-Queen's University Press, 2006) at 318; Arthurs, ibid. at 232.

42 Leah F. Vosko, "Precarious by Choice? Gender and Self-Employment" in Vosko, ibid. at 67; Low-paid employment and moving up: A closer look at full-time, full-year workers, (Aug 2004), online: Statistics Canada <http://www.statcan.gc.ca/pub/75f0002m/75f0002m2004009-eng. pdf> at 15; Fudge, supra note 25.

43 Low-paid Work and Economically Vulnerable Families over the Last Two Decades, (April 2005), online: Statistics Canada <http://www.statcan.gc.ca/pub/11f0019m/11f0019m2005248-eng. pdf> at $15,16,19$.

44 Ibid.

45 Stephanie Bernstein et al., "Precarious Employment and the Law's Flaws: Identifying Regulatory Failure and securing Effective Protection for Workers" in Vosko, supra note 41, 203 at 215217.

46 Reference re Validity of s. 5(a) of Dairy Industry Act (Canada), [1949] S.C.R. 1, [1949] 1 D.L.R. 433 at paras. $142-145$ per Rand J. (as he then was).

47 Canada (Procureure générale) c. Hydro-Québec, [1997] 3 S.C.R. 213, 151 D.L.R. (4th) 32 at paras. 121-123.

48 R. v. Sault Ste. Marie (City of), [1978] 2 S.C.R. 1299, 85 D.L.R. (3d) 161 at paras. 60-61 (employment standards violations likely fall into the category of public welfare offences, not "true crimes"). 
offences because they can be ruinous for the victims, disproportionately affect vulnerable people, and cause injury to society as a whole. There should be real consequences for breaking employment laws.

\section{PRIVATE PROSECUTIONS AS A TOOL TO PROTECT WORKERS' RIGHTS}

Before explaining how private prosecutions can improve compliance with employment standards, I will explain what they are and where they come from. In the normal course of events, a criminal prosecution is commenced when a police officer files an "information" with the court. This is the document that names the accused and briefly outlines the alleged offence. The court then decides whether to compel the appearance of the accused. The prosecution is then conducted by counsel employed by the Attorney General. However, any member of the public may commence a prosecution by swearing an information before a Justice of the Peace, and then may go on to conduct the prosecution if the Attorney General does not decide to intervene and take over the case. This is a private prosecution.

\section{A. The History of Private Prosecutions}

Historically, most prosecutions were private and were far different from their modern counterparts. ${ }^{49}$ Although there were both public and private prosecutions in ancient Rome, there were no public prosecutors in classical Athens or in the early English courts. ${ }^{50}$ English prosecutions between the $7^{\text {th }}$ and $10^{\text {th }}$ century were often motivated by the fact that the victim-prosecutor could make a monetary settlement with the accused.$^{51}$ In pre- $19^{\text {th }}$ century England there were a number of common but changing persons who acted as prosecutor, including the victim, the prominent persons from a locality, religious figures, and eventually, civil servants from the office of the Attorney General. ${ }^{52}$

In 1883, Sir James Fitzjames Stephen, a prominent British criminal law scholar, noted how Britain and its colonies were peculiar in leaving the job of prosecuting to private persons or to public officers who have no special powers beyond those held by all persons. ${ }^{53}$ By contrast, France and most continental countries had public prosecutors with special powers. Stephen suggests two origins of the British practice. ${ }^{54}$ First, the early criminal law practices of appeals and private accusations were very similar to civil proceedings and were therefore conducted by private persons. Second, and more recently, Parliament allowed the character of trials by jury to evolve without adequately legislating for public prosecutors.

49 Daniel Klerman, "Settlement and the Decline of Private Prosecution in Thirteenth-Century England" (2001) 19 L.H.R. 1 at 2.

50 Ibid.; Sir James Fitzjames Stephen, A History of the Criminal Law of England, vol. 1 (London: Macmillan, 1883) at 42 [Stephen, History of Criminal Law].

51 Klerman, supra note 49 at 7.

52 Andrew Sidman, "The Outmoded Concept of Private Prosecution" (1975-1976) 25 Am. U. L. Rev. 754 at 757; Stephen, History of Criminal Law, supra note 50 at 68 (See generally Chapter III - Early English Law).

53 Stephen, ibid. at 493-496.

54 Ibid. at 496-499. 
Originally, jurymen could make accusations, give evidence and make inquiries. Their role gradually evolved to something closer to the role of the modern jury, which adjudicates based on the evidence presented to it. However, Parliament failed to create a body with special powers or duties to assume the inquisitorial role once played by the jurymen. As Stephen writes,

It was thus by a series of omissions on the part of the legislature to establish new officers for the administration of justice as the old methods of procedure gradually changed their character, that English criminal trials gradually lost their original character of public inquiries, and came to be conducted in almost precisely the same manner as private litigations. ${ }^{55}$

As discussed below, private prosecutions continue to fill a gap left by government inaction.

In Britain, the Attorney General has long had the power to commence and conduct a prosecution. ${ }^{56}$ However, the Attorney General historically had neither the duty to prosecute nor any special powers to commence a prosecution beyond those possessed by any lay person. England's modern system of public prosecutions was not set up by Parliament until 1879 (with the creation of the Director of Public Prosecutions) and did not become the primary means of prosecution until even later. ${ }^{57}$ Connecticut was the first American state to set up a system of public prosecutors in 1704 with the rest of the country eventually following suit. ${ }^{58}$ In Canada, the transition from predominantly private to predominantly public prosecution was slow, with private prosecutions never completely disappearing. ${ }^{59}$ In the present day the majority of prosecutions are public. However, it is common for victims of crimes such as assault to privately lay charges, commencing a prosecution when a police officer is unwilling to do so. Similarly, environmentalists sometimes privately prosecute when the government fails to enforce environmental laws. ${ }^{60}$

\section{B. The Law of Private Prosecutions}

The power of any person to commence a prosecution of a provincial offence is found in Part III of the Provincial Offences Act. Section 23 states that "any person" may lay an information before a Justice. This commences the prosecution. The Justice will issue a summons where she believes "that a case for so doing is made out. ${ }^{{ }^{61}}$ A summons will then be served by a Provincial Offences Officer. ${ }^{62}$

\footnotetext{
5 Ibid. at 497.

6 Ibid. at 68.

57 Ibid. at 760; Klerman, supra note 49 at 501.

58 Sidman, supra note 52 at 763.

59 Philip C. Stenning, Appearing for the Crown (Cowansville: Brown Legal Publications, 1986) at $33-154,263$.

60 James S. Mallet, Enforcing Environmental Law: A Guide to Private Prosecution (Edmonton: Environmental Law Centre, 2004).

61 POA, supra note 21, s. 24.

62 Ibid. s. 26.
} 
In the employment standards context service would require the cooperation of the Ministry or the help of civil servants working with the Justice of the Peace. ${ }^{63}$ The right to commence a prosecution by laying an information against an offender has been called a "fundamental precept" and a "citizen's fundamental and historical right" by the Supreme Court of Canada. ${ }^{64}$

The power to conduct a private prosecution is found in the common law, as was unequivocally confirmed in $R$. v. Schwerdt:

Under English law there is, I conclude, not the slightest doubt that a private prosecutor ... can at the present day in the absence of intervention by the Crown, carry through all its stages a prosecution for any offence. ${ }^{65}$

In addition, the definition of "Prosecutor" in section 1 of the POA includes "the person who issues a certificate or lays an information." Through the common law and the POA, prosecutions of provincial offences can be commenced and conducted by private citizens. Similar sections of the Criminal Code give citizens the power to prosecute federal offences. ${ }^{66}$

\section{Private Prosecutions in Context: Regulatory Gaps and Governmental Failures}

Historically, private prosecutions have waxed and waned in proportion to the effectiveness of the public prosecutorial system. Craig B. Little and Christopher P. Sheffield have documented examples where the state's system of public prosecutions has not adapted to social changes quickly enough to satisfy social the demands placed on it. ${ }^{67}$ For example, vigilantism arose in the United States in the 1800s (an extreme form of private criminal law enforcement) as settlers moved into territory without sufficient governmental control and social norms. ${ }^{68}$ Similarly, prosecution societies arose in England around the time of the Industrial Revolution. These societies pooled funds that the member merchants and landholders could draw from if they needed to prosecute persons that harmed their property. ${ }^{69}$ These prosecution societies arose because the state apparatus at

63 All Employment Standards Officers are Provincial Offences Officers and therefore can serve summonses.

64 Quebec (A.G.) v. Lechasseur, [1981] 2 S.C.R. 253, 128 D.L.R. (3d) 739 at 261; R. v. Dowson, [1983] 2 S.C.R. 144, 2 D.L.R. (4th) 507 at 155.

65 (1957), 23 W.W.R. 374, 27 C.R. 35 (B.C. Sup. Ct.) at para. 12; Sir James Fitzjames Stephen, $A$ General View of the Criminal Law of England, $2^{\text {nd }}$ ed. (London: Macmillan, 1890) at 156 [Stephen, General View].

66 See Criminal Code, R.S.C. 1985, c. C-46, s. 2, 504 (Re: definition of "prosecutor" and persons entitled to lay an information); Stenning, supra note 59 (for an exhaustive analysis of the power of a private prosecutor in various Criminal Code proceedings).

67 "Frontiers and Criminal Justice: English Private Prosecution Societies and American Vigilantism in the Eighteenth and Nineteenth Centuries" (Dec 1983) 48:6 American Sociological Review 796 at 804 .

68 Ibid. at 803 .

69 Ibid. at 798-800. 
the time was unable to deal with the effects of the transition from a rural/agricultural to an urban/industrial society. ${ }^{70}$

The current need for employment standards prosecutions may be due to a similar phenomenon. Perhaps the executive branch of the state has not yet adapted to the economic, social and political changes that have spurred increasing regulation over the past hundred years. Generally speaking, this period has seen the creation and growth of previously unknown regulatory regimes. ${ }^{71}$ The past thirty to forty years have been particularly active with "explosive growth" in programs regulating the workplace, consumer rights, and the environment. ${ }^{72}$ For example, most employment standards in Ontario were enacted in the late 1960s and early 1970s, a period characterised by an expanding workforce, increasing unionization, industrialization and mass production. ${ }^{73}$ Almost without exception, studies of these new regulatory regimes note the limited use of prosecutions and the ineffectiveness of compliance strategies. ${ }^{74}$ It seems that the public prosecutorial system has not learned how to cope with the social and economic changes that have spurred these increases in regulation. Private prosecutions of ESA violations would be an example of civil society responding to a failure of the government to adapt to changing social conditions.

While private prosecutions appear to be unknown in the non-union employment standards context, ${ }^{75}$ they have become relatively important in the environmental realm. Both are cases where the state cannot or will not meet the prosecutorial demands caused by increasing regulation. Private prosecutions have arisen in the environmental context perhaps because illegal environmental practices affect the rich and poor alike, and also because the private complainant is sometimes entitled to a portion of the fine. ${ }^{76}$ That private prosecutions of employment standards violations have not yet occurred is more likely the result of the social position of the victims rather than any problems with the efficacy of the tool. Because the victims are often vulnerable their rights are not vindicated

70 Ibid. at 804

71 Becker, supra note 12 at 169 ("Since the turn of the century, legislation in Western countries has expanded rapidly to reverse the brief dominance of laissez faire during the nineteenth century. The state no longer merely protects against violations of person and property through murder, rape, or burglary ...”); Laura Jones \& Stephen Graf, Canada's Regulatory Burden (August 2008), online: The Fraser Institute <http://www.fraserinstitute.org/commerce.web/product_files/ Aug01ff.pdf> (documenting the growth of social regulation in Canada).

72 Keith Hawkins \& John H. Thomas, “The Enforcement Process in Regulatory Bureaucracies” in Keith Hawkins \& John M. Thomas, eds., Enforcing Regulation (Boston: Kluwer Nijhoff, 1984) 3 at 4; William Lilley III \& James C. Miller III, “The New 'Social Regulation”” (Spring 1977) 47 Public Interest 49; Jones \& Graf, ibid.

73 Thomas, supra note 25 at 102-104.

74 Dave Cowan \& Alex Marsh, “There's Regulatory Crime and Then There's Landlord Crime: from 'Rachmanites' to 'Partners”' (2001) 64 Mod. L. Rev. 831 at 835; Bridget M. Hutter, "Variations in Regulatory Enforcement Styles" (1989) 11 Law \& Pol'y 153 at 154; Richard Brown, "Theory and Practice of Regulatory Enforcement: Occupational Health and Safety Regulation In British Columbia” (1994) 16 Law \& Pol'y 63 at 63.

75 I have been unable to find any reference to a private prosecution under the ESA either in journal articles or reported cases.

76 See e.g. Fishery (General) Regulations, S.O.R./93-53, s. 62 (half of the penalty from certain Fisheries Act offences must be paid to the private person that laid the information). 
in either the public or private realm.

Private prosecutions have long been seen as a democratic tool to counter the absolute discretion of the prosecutor and to remedy lazy, negligent, corrupt or ineffective law enforcement. ${ }^{77}$ For example, Pinochet's arrest in London was due to an extradition order pursuant to a private prosecution initiated in Spain (public authorities refused to prosecute). ${ }^{78}$ Private prosecutions have been similarly used in a number of European countries by activists seeking to enforce international human rights norms. ${ }^{79}$ Private prosecutions have an equally powerful role in the purely domestic context. When journalist Dele Giwa was killed in Nigeria, the accused members of the government security forces could only be brought to court through a private prosecution. ${ }^{80}$ Many environmental offenders are only brought to justice in Canada through private prosecutions. ${ }^{81}$ Similarly, private prosecutions of employment standards violations are required because the lack of law enforcement leaves the victim's rights unprotected. The Law Reform Commission of Canada has said that "the private prosecution has a practical, responsible and real role to play in our criminal justice system." ${ }^{" 2}$ It is a tried and tested public interest tool that civil society should be taking full advantage of.

\section{Private Prosecutions of ESA Offences}

Private prosecutions have long been used as a tool both by and against unions ${ }^{83}$ False perceptions about the difficulties and expense of private prosecutions may explain why they have not been used in the context of ESA offences. Many commentators note that private prosecutions are too expensive, complex, and uncertain to be viable in the majority of cases. ${ }^{84}$ These perceived obstacles,

77 Kent Roach \& Michael J. Trebilcock, "Private Enforcement of Competition Laws" (1996) 34 Osgoode Hall L. J. 461 at 473-475; Peter L. Davis, "The Crime Victim's 'Right' to a Criminal Prosecution: A Proposed Model Statute for the Governance of Private Criminal Prosecutions" (1988-1989) 38 DePaul L. Rev. 329 at 373; Isabella Okagbue, "Private Prosecution in Nigeria: Recent Developments and Some Proposals” (1990) 34 J. Afr. L. 53 at 59.

78 Julio Perez Gil, "Private Interests Seeking Punishment: Prosecution Brought by Private Individuals and Groups in Spain" (April 2003) 25:2 Law \& Pol'y 151 at 165.

79 See e.g. Beth Stephens, "Individuals Enforcing International Law: The Comparative and Historical Concept” (2002-2003) 52 DePaul L. Rev. 433 at 454-455; Ellen Lutz \& Kathryn Sikkink "The Justice Cascade: The Evolution and Impact of Foreign Human Rights Trials in Latin America" (2001) 2 Chicago J. Int'l L. 1 (for evidence that these international efforts spur domestic willingness to try human rights cases in the developing nations themselves).

80 Okagbue, supra note 77 at 57-59 (Tragically, the private prosecution failed in the face of the government's procedural maneuvering and a legislative amendment that outlawed private prosecutions in these circumstances.).

81 Mallet, supra note 60; Kernaghan Webb, "Taking Matters Into Their Own Hands: The Role of Citizens in Canadian Pollution Control Enforcement” (1990-1991) 36 McGill L. J. 770.

82 Law Reform Commission of Canada, Private Prosecutions (Ottawa: Law Reform Commission of Canada, 1986).

83 Judy Fudge \& Eric Tucker, Labour Before the Law: The Regulation of Workers' Collective Action in Canada 1900-1948 (Toronto: Oxford University Press, 2001) 38, 87, 99 (re historical relevance); See e.g. Hogan v. Peddle (1984), 48 Nfld. \& P.E.I.R. 275, 142 A.P.R. 275 (Nfld. Prov. Ct.)(private prosecution by a union); Iron Ore Co. of Canada v. United Steel Workers of America, Local 5795 (1979), 20 Nfld. \& P.E.I.R. 27, 53 A.P.R. 27 (Nfld. C.A.) (private prosecution against a union).

84 Gilles Trudeau \& Thomas Kuttner, "Sanctions for Violation or Non-Implementation of 
coupled with the vulnerable position of non-unionized workers, could be why employment standards violations have not been prosecuted privately. However, these are unfounded fears because, at a closer look, private prosecutions of ESA offences would not be expensive, complex, or uncertain.

All violations of the ESA are offences and can be privately prosecuted. These violations can be grouped into two categories: "first instance" offences and "failure to comply" offences. ${ }^{85}$ In a "first instance" offence, an employer directly contravenes a section of the ESA. For example, it is an offence for an employer to fail to pay wages or to fire an employee for trying to exercise their rights under the ESA. Although "first instance" offences can be prosecuted, especially where they are particularly egregious, this is not an efficient use of resources. The prosecutor must meet the heavy burden of proving the elements of the offence beyond a reasonable doubt while the burden in a hearing before an Employment Standards Officer is a balance of probabilities. An unreasonable amount of evidence and many witnesses would be required to prove the elements of the various "first instance" offences.

Just as the Ministry does, victims and legal clinics would likely only prosecute "failure to comply" offences. Under section 132 of the ESA it is an offence to fail to comply with an order made under the ESA. After an Officer has issued an order (most often for the payment of wages) the employer has thirty days to pay or appeal. If that period passes before payment is made, the employer has failed to comply and has, therefore, committed an offence. To convict the employer, the prosecution must prove first, that an order was issued against the defendant; second, that the order was served on the defendant; and third, that the order was not paid by the defendant within thirty days. If convicted, the court must order the employer to pay any unpaid wages to the director (a restitution order), may levy a fine, and may imprison an individual accused ${ }^{86}$ The issuance of a restitution order triggers the obligation that the Ministry "attempt" to collect the unpaid wages. ${ }^{87}$ Due to special evidentiary rules in the ESA, documents can be used to establish all the elements of a failure to comply offence. ${ }^{88}$ Proof would consist of three certificates prepared, signed and certified by the Ministry. Because this has not been attempted before, the first private prosecution under the ESA may require a significant amount of research and resources. However, the novelty also presents an opportunity to make a long-lasting contribution to public interest law by gaining experience with this powerful tool. Once experience in this field has been gained, prosecutions would not be onerous and perhaps could be expanded to other areas of poverty law where laws meant to protect marginalized persons are not enforced by the government.

Canadian Labour Standards" (1989-1990) 11 Comp. Lab. L.J. 164 at 176; Adams, supra note 6 at 55; Peter Burns, "Private Prosecutions in Canada: The Law and a Proposal for Change" (1975) 21 McGill L. J. 269 at 286-287.

85 I use this categorization only for explanatory purposes - I have not seen such a distinction made elsewhere.

86 ESA, supra note 3, part XXV. The punishments vary where the accused is a corporation or has previous convictions and depending on the specific violation.

87 Ibid.

88 See text accompanying note 138 . 


\section{E. Assessing the Effectiveness of ESA Private Prosecutions}

\section{Deterrence}

The most obvious benefit of private prosecutions is that they would deter other potential offenders (general deterrence) and would make employers think twice before re-committing (specific deterrence). If found guilty, a company is liable for a fine of up to $\$ 100,000$. $^{89}$ An individual can be fined up to $\$ 50,000$ or sentenced to a maximum of twelve months in prison. The fines are even higher for repeat offenders. The dismal rate of collections of orders would suggest that offenders do not take the Ministry very seriously. ${ }^{90}$ The threat of a large fine, possible imprisonment and the stigma of a criminal conviction may reduce this flagrant disregard for the law.

Of course, the theory and empirical evidence on deterrence is hotly debated. Many scholars criticize the efficacy of deterrence models of regulatory enforcement, especially as compared to more conciliatory compliance models, noting that hard line approaches can destroy necessary cooperation and provoke a legalistic backlash. ${ }^{91}$ Much of this debate depends on assumptions about the typical offenders: the employer making purely economic calculations will break laws whenever profitable; the employer who believes in the law may only break it when he or she thinks it operates unfairly; and the incompetent boss may simply not know the rules. ${ }^{92}$ However, almost all scholars agree that some threat of punishment is necessary, perhaps through the use of a "tit for tat" strategy where the regulator only punishes after persuasion fails. ${ }^{93}$ With an average of fewer than 10 prosecutions per year, and more than 10,000 confirmed violations per year, employers effectively face no punishment in Ontario. ${ }^{94}$

A number of studies have analysed the effectiveness of occupational health and safety prosecutions, often drawing on the kind of deterrence theory discussed above. Although there are good reasons and some evidence to believe that public prosecutions work, some studies fail to find a connection between punishment and compliance. ${ }^{95}$ However, it is clear that the Ministry believes that

89 ESA, supra note 3, s. 132.

90 WAC 2007, supra note 6 at 58 (In 2005 only 16\% of the uncollected claims were from employers who were bankrupt or in receivership. Many simply refuse to pay, while some evade the Ministry by changing their business name.).

91 Albert J. Reiss, Jr., "Selecting Strategies of Social Control Over Organizational Life" in Hawkins \& Thomas, supra note 72, 23 at 23 (defining the compliance and deterrence models); Keith Hawkins, "Compliance Strategy, Prosecution Policy, and Aunt Sally: A Comment on Pearce and Tombs” (1990) 30:4 Brit. J. Crim. 444 at 451-452 (loss of cooperation and potential backlash).

92 Robert A. Kagan \& John T. Scholz, “The 'Criminology of the Corporation' and Regulatory Enforcement Strategies" in Hawkins \& Thomas, supra note 72, 67 at 95 (three images of corporate non-compliance).

93 Brown, supra note 74 at 87.

94 Figures taken from statistics provided to the author by the Ministry of Labour. Figures refer to averages from 1997 to 2007 on a per complaint basis (multiple prosecutions or violations arising from one complaint/file are counted only once). The number of violations refers to violations that are confirmed by a finding of an Employment Standards Officer. The true number of violations is much higher (see footnote 19). For published figures see footnotes 24 to 27 .

95 Brown, supra note 74 at 87; R.M. Brown, "Administrative and Criminal Penalties in the Enforcement of Occupational Health and Safety Legislation" (1992) 30 Osgoode Hall L. J. 691 at 703-705. 
punishment can be used to enforce workplace safety laws. Between 1999 and 2004, the Ministry achieved an average of over 380 convictions per year under health and safety legislation and only sent an average of four cases for prosecution under employment standards legislation during the same period. ${ }^{96}$

Roy Adams discusses three types of delinquent employers: first, the sulkers are immobile and solvent but refuse to pay, sometimes because of a personal dispute; second, some deliberately defraud by disappearing, using multiple bank accounts or other means; and third, some are bankrupt. ${ }^{97}$ When an employer simply cannot pay, an additional fine cannot be effective. Prosecutions would be most effective against the fraudsters and repeat offenders. They would deter those who intentionally or recklessly violate workers' rights. ${ }^{98}$ Criminal charges should make even the bankrupt employer think twice before starting up business again without ensuring that his or her employees can be paid.

Some excellent proposals have been made to create an efficient and cost effective system of administrative penalties that could serve to deter bad bosses. ${ }^{99}$ Harry Arthurs' recent review of federal employment standards proposes such a system but also recommends retaining criminal prosecutions for the worst offenders. ${ }^{100}$ Prosecutions carry a high level of stigma which acts as a significant informal aspect of punishment, multiplying the mere monetary effect of a fine. ${ }^{101}$ Prosecutions would promote deterrence because they are the only significant form of punishment in the ESA. They are currently far under-utilized but can send an effective message to employers who recklessly or intentionally violate workers' rights.

\section{Collection of Orders}

One disappointing aspect of private prosecutions is that they do not provide any additional tools to effect collection from a delinquent employer. One problem with the current system is that only the Ministry has the power to collect the debts from orders to pay. When the Ministry does not actively pursue collections, the unpaid worker or their legal representative cannot take steps to attempt to effect collection. A restitution order made pursuant to a private prosecution has the same problem because the employer is ordered to pay the Ministry, not the employee directly. ${ }^{102}$

A restitution order does not even give the Ministry more tools for their internal collections process. As it stands, the Ministry can file an Employment Standards Officer's order in a court and then collect from the offender as if the Officer's order was a regular judgment from that court. ${ }^{103}$ In terms of collection, an order that has been filed in court is equivalent to a restitution order issued

96 "Report Card: Health and Safety Statistics" (August 2008), online: Ontario Ministry of Labour <http://www.labour.gov.on.ca/english/hs/stats/index.html>; Auditor General 2004, supra note 11 at 244; Note that there can be multiple charges in a single file sent to prosecution.

97 Adams, supra note 6 at 53-55.

98 Becker, supra note 12 at 176.

99 R.M. Brown, supra note 95 at 694; Arthurs, supra note 6 at c. 9.

100 Arthurs, ibid. at 221.

101 R.M. Brown, supra note 95 at 734

102 ESA, supra note 3, s. 135. A restitution order is an order to pay the Director of Employment Standards who in turn is obliged to collect the funds and remit them to the employee.

103 Ibid. s. 126. 
pursuant to a prosecution. Both can be collected using the same mechanisms set out in section 60 of the Rules of Civil Procedure. ${ }^{104}$ However, an employer would presumably be much more likely to pay when faced with the penalties and stigma discussed above.

\section{Intervention by the Attorney General}

The Attorney General has wide powers to intervene in a private prosecution. ${ }^{105}$ After intervening they can assume conduct of the case and proceed, return carriage of the case to the private prosecutor, carry the case in cooperation with the private prosecutor, or enter a stay. ${ }^{106}$ If a case has been stayed, the private prosecutor must meet the exceedingly high burden of proving "flagrant impropriety" in order to challenge this prosecutorial discretion on judicial review. ${ }^{107}$ This standard may be met with "proof of misconduct bordering on corruption, violation of the law, bias against or for a particular individual or offence." ${ }^{108}$ In some cases, intervention by the Attorney General can be a good thing. If the Attorney General decides to assume conduct of the case, the resources of the private prosecutor are freed up to pursue other matters.

However, generally speaking, the Attorney General's power to intervene greatly weakens private prosecutions as a public interest tool because a stay from the Attorney General will almost always thwart the private prosecutor. ${ }^{109}$ However, judging from the history of environmental prosecutions, the Attorney General in Ontario will likely not stay valid claims. In other provinces (most notably in Alberta and British Columbia) there appears to be a policy of intervening and staying private prosecutions. ${ }^{110}$ In the very least private prosecutions can serve the democratic function of bringing decisions not to prosecute into the public spotlight. ${ }^{111}$

\section{Rights of the Accused}

Some commentators criticise private prosecutions for breaching the rights of the accused. The most serious claim is that private prosecutions deny the accused a trial by a neutral prosecutor. ${ }^{112}$ In Canada, the prosecutor has a duty to

104 R.R.O. 1990, Reg. 194.

105 For criminal prosecutions this is clearly set out in sections 579, 579.01 and 579.1 of the Criminal Code, supra note 66. For provincial offences, it is implied by the POA, supra note 21, s. 32.

106 Although this is the case in most common law jurisdictions, it is worth noting that in Spain, a private prosecutor is not subordinate, cannot be ousted by the Attorney General and can intervene in all parts of a proceeding. See Gil, supra note 78 at 159.

107 Krieger v. Law Society (Alberta), [2002] 3 S.C.R. 372 at para 49; See generally Keith Ferguson, "Challenging the Intervention and Stay of an Environmental Private Prosecution" 13 J. Envtl. L. \& Prac. 153.

108 Kostuch v. Alberta (A.G.) (1998), 33 Alta. L.Rev. (3d) 225, 43 C.R. (4th) 81 (C.A.).

109 Bryce C. Tingle, "The Strange Case of the Crown Prerogative Over Private Prosecutions or Who Killed Public Interest Law Enforcement” (1994) 28 U.B.C.L. Rev. 309.

110 John Werring, "Handbook: How to Gather and Present Evidence for the Purposes of the Laying of Charges in a Private Prosecution," Online: Sierra Legal Defence Fund <http://www. ecojustice.ca/reports/handbook.html>.

111 Webb, supra note 81 at 785 .

112 Joan Meier, “The 'Right' to a Disinterested Prosecutor of Criminal Contempt: Unpacking Public and Private Interests" (1992) 70 Wash. U.L.Q. 85 at 108-110; Sidman, supra note 52 at 773 to 780 . 
seek justice, not simply to advocate for a conviction. ${ }^{113}$ The fear is that the private prosecutor, by having partisan interests, would overstep the bounds of the prosecutor's ethic in their conduct of the trial, leading to wrongful convictions. This is not a serious concern in the context of ESA "failure to comply" offences. In a prosecution of a "failure to comply" offence, an unbiased Officer has already found fault with the employer and has issued an order. The employer has the right to appeal that order to the Labour Relations Board where the issues and facts will be freshly heard. ${ }^{114}$ The private prosecutor merely proves that the final order has been ignored. There are so few facts to be determined in trial - basically that an order has not been paid - that there is little chance that an innocent person could be convicted.

Prosecutors are also supposed to follow uniform and predetermined guidelines when deciding whether or not to prosecute. They should apply those guidelines consistently and should only choose to prosecute when that decision is justified. Critics claim that the private prosecutor will not be as even handed and will prosecute where the crown would usually not choose to do so. ${ }^{115}$ However, as it stands, the current written policy of the Ministry regarding prosecutions is not being followed or applied fairly. ${ }^{116}$ Far more prosecutions would occur if the Ministry acted in all cases that fit the criteria in their policy. Private prosecutions, by increasing the number of prosecutions, would actually increase consistency. Furthermore, the Attorney General always has the power and obligation to intervene where he or she believes proceedings have been unfairly commenced against the accused. Finally, legal clinics can and should develop standard prosecution policies if they begin to conduct a significant number of private prosecutions. By following a prosecution policy, the legal clinic can avoid the charge of bias. The outline of a suggested policy is given in Part IV, below.

Private prosecutions of employment standards violations do not pose a significant threat to the rights of the accused. However, any prejudice to the accused must be balanced against the rights of the victim. Where an offence has been committed the victim should be able to look to the state and the courts for redress. ${ }^{117}$ In the employment standards context they cannot do so. Private prosecutions provide the only judicial means to vindicate a victim's rights when the government fails to do so. On balance, private prosecutions would promote the interests of justice because the significant rights of the victim outweigh the small possibility of prejudice to the accused.

113 Boucher v. R. (1954), [1955] S.C.R. 16, 20 C.R. 1, at 23-24 [Boucher].

114 ESA, supra note 3, s. 116.

115 See Meier, supra note 112; Sidman, supra note 52.

116 Ontario Ministry of Labour, Employment Standards Procedures Manual (Toronto: Ministry of Labour, November 15, 2002, revised up to December 5, 2003) at 7.7.1 [Procedures Manual] (this is an internal procedures manual for ESOs which can be obtained from the Ministry and would be a useful reference in undertaking private prosecutions); For example, although the policy states that all failure to comply offences "shall be considered for prosecution", the small number of prosecutions, compared to the high number of failure to comply offences, suggests that this does not actually take place.

117 Davis, supra note 77 at 337. 


\section{Systemic strategies}

Some commentators criticise private prosecutions for masking the deficiencies in the public system. ${ }^{118}$ They argue that aggrieved parties should advocate for changes to the public prosecutorial system instead of going around it. In the employment standards context this would mean lobbying the Ministry of Labour to increase public prosecutions. However, the need to bring private prosecutions highlights these problems with the system. The few legal clinics that provide employment related legal support mainly seek to get employees their unpaid wages. Private prosecutions offer a more systemic solution because they have the potential to change the practices of bad employers through deterrence and the gradual adoption of new norms. Private prosecutions would also increase pressure on the government to provide the funding required for adequate public prosecutions and collections.

\section{Treating Employment Standards Violations as Crimes}

It is very disempowering when an employer refuses to obey a court order without punishment. The worker is required to go through a lengthy and intimidating legal process only to discover that it was all for nothing. When a worker has their rights violated they become a victim. If their rights are not protected by the law the stigma of victimization remains and perhaps the next time their rights are violated they will not bother to report it to the Ministry. Perhaps they will also be less willing to negotiate with future employers and to stand up for their rights. The already marginalized worker will end up feeling even more frustrated and powerless than they would have if they had not bothered to complain to the Ministry in the first place.

In the very least, a private prosecution avoids sending the disempowering message that the law does not protect you. A prosecution sends the message that a violation of an employee's rights deserves punishment from the state. In particular, it sends the message that marginalized workers cannot be abused with impunity. It also opens some avenues for client participation through the decision whether or not to prosecute and through the conduct of the prosecution itself. Private prosecutions of employment standards violations would vindicate workers' rights and in doing so would send a powerful message that even the most marginalized workers actually have rights that they are able to stand up and fight for.

As Fred Kaufman points out, "it is the essence of a crime that it is a wrong of so serious a nature that it is regarded as an offence, not merely against an individual, but against the State itself." ${ }^{119}$ An employment standards violation can be such a serious wrong that it is an offence against the state and society - many violations are crimes. If we take those crimes seriously, the legal community should be prosecuting them when the government fails to do so. Violations can lead to chronic poverty and disproportionately harm women, new Canadians, single income families, and low-income workers. ${ }^{120}$ Society as a whole suffers when workers'

118 Gil, supra note 78 at 165 .

119 Fred Kaufman, “The Role of the Private Prosecutor: A Critical Analysis of the Complainant's Position in Criminal Cases" (1960-1961) 7 McGill L. J. 102 at 102.

120 See the text accompanying notes 36 to 44 . 
rights are not vindicated. Private prosecutions would acknowledge the seriousness of employment standards violations, vindicate the rights of vulnerable workers, empower them, and recognise the fundamental importance of work.

\section{F. Taking Private Prosecutions Beyond the ESA}

As Professors Kent Roach and Michael J. Trebilcock note, private prosecutions "allow individuals and groups to compete over increasingly pluralistic understandings of the public interest." 121 Private prosecutions could be used beyond the ESA, in other areas of social regulation where people are denied criminal justice because the state does not devote sufficient resources to enforcement. For example, the nastiest landlords or those who defraud recent immigrants could be privately prosecuted. Of course, each area of law is governed by its own legislation and would have different considerations. For example, a prosecution under the Labour Relations Act, $1995^{122}$ can only be initiated by a private party with prior consent from the labour board. ${ }^{123}$

Private prosecutions are particularly appropriate for ESA offences because of the simplicity of "failure to comply offences," the egregious nature of offences that currently go unpunished and the present lack of alternative methods of deterrence. However, the problem of lax regulatory enforcement is by no means limited to employment standards. ${ }^{124}$ Nor is the problem limited to remedial laws - it has been said that private parties should be able to enforce competition and securities laws. ${ }^{125}$ Private prosecutions, or similar statutory processes, are relevant tools whenever beneficial social regulation increases while enforcement budgets remain the same.

\section{IMPLEMENTATION AND PRACTICAL CONSIDERATIONS}

In the above sections I examined some gaps in the employment standards regime in Ontario, showed how they are socially destructive and discriminatory, argued that private prosecutions can help fill those gaps, and described how using private prosecutions in this way makes sense in light of the history of private prosecutions as a public interest tool. I will now discuss some of the practical implications of privately prosecuting employment standards violations and suggest a policy that could be used to decide when to prosecute.

\section{A. The Prosecutor's Duties and Ethics}

Prosecutors have duties extending beyond what is expected of other litigants. The Supreme Court of Canada characterises this as a public duty that must be executed fairly:

It cannot be overemphasized that the purpose of a criminal

121 Supra note 77 at 474

122 S.O. 1995 , c. 1

123 Ibid. s. 109.

124 See footnote 74 .

125 Roach \& Trebilcock, supra note 77; Owen Lippert, "The Economics of a Private Right to Prosecute" (March 1997) Can. Law. 3 at 10. 
prosecution is not to obtain a conviction, it is to lay before a jury what the Crown considers to be credible evidence relevant to what is alleged to be a crime. Counsel have a duty to see that all available legal proof of the facts is presented: it should be done firmly and pressed to its legitimate strength but it must also be done fairly. The role of prosecutor excludes any notion of winning or losing; his function is a matter of public duty than which in civil life there can be none charged with greater personal responsibility. It is to be efficiently performed with an ingrained sense of the dignity, the seriousness and the justness of judicial proceedings. ${ }^{126}$

Both the provincial and federal policy guidelines for prosecutors stress the importance of fairness and moderation. ${ }^{127}$ This creates certain obligations, such as the requirement that charges be laid only if there is a "reasonable prospect of conviction" and only in accordance with the "public interest." Similarly, private prosecutors must be careful to prosecute in the name of justice and not to be over-zealous in the conduct of prosecutions. All parties involved, including the wronged worker, must be aware that a prosecution is not a partisan matter.

In a private prosecution the person who swears the information (the informant) acts as the prosecutor unless the Attorney General intervenes in the proceedings. The choice of informant thus involves balancing the special duties of the prosecutor with the goal of client empowerment. In a private prosecution the regular citizen who lays the information wields the coercive power of state machinery, including the power to imprison the accused. ${ }^{128}$ Depending on the circumstances, a legal professional may want to be the informant in light of the seriousness of the proceedings. Of course, the employee must be party to the decision making process. This may be less empowering, but it may be irresponsible to do otherwise.

\section{B. Disclosure}

The private prosecutor must also be aware of the duty to disclose all relevant information to the accused. ${ }^{129}$ All relevant material must be disclosed whether or not the prosecutor intends to introduce it at trial and whether or not it is inculpatory or exculpatory. ${ }^{130}$ Disclosure requirements may pose a problem for legal clinics as an accused may request documents over which the client/worker wishes to retain solicitor-client privilege. Information can sometimes be withheld by relying on the law of privilege. However, solicitor-client privilege does not always constitute a reasonable limit on the accused's constitutional right to

126 Boucher, supra note 113 at 23-24.

127 "Crown Policy Manual - Preamble," online: Ministry of the Attorney General <http://www. attorneygeneral.jus.gov.on.ca/english/crim/cpm/> [Ontario Crown Policy]; "The Federal Prosecution Service Deskbook,” online: Department of Justice Canada < http://www.justice. gc.ca/eng/dept-min/pub/fps-sfp/fpd/> at s. 9.3 [Federal Crown Policy].

128 Meier, supra note 112 at 108-110.

129 R. v. Stinchcombe, [1991] 3 S.C.R. 326, 18 C.R.R. (2d) 210.

$130 \mathrm{Ibid}$. at para 29. 
make a full answer and defence. ${ }^{131}$ The worker's documents may not need to be disclosed because they are not likely to be relevant to the actual offence of failing to pay an order. However, there is a risk that a court could err on the side of disclosure and order production. Because all documents may need to be disclosed, legal clinics would need to vet the file for such problems prior to laying charges and discuss this possibility with the client. When the Ministry prosecutes they disclose the entire file in the possession of the Employment Standards Officer who investigated the matter. ${ }^{132}$ Prior to pressing charges, the private prosecutor could request this file from the Ministry under the Freedom of Information and Protection of Privacy Act. ${ }^{133}$ The Ministry file, along with the client's civil file (excluding documents covered by privilege), would be disclosed to the accused.

\section{Media and Communications}

In light of their public duty, when communicating with the media prosecutors should not offer personal opinions, should avoid creating a sensation, and above all should protect the integrity of the trial. ${ }^{134}$ Prosecutors must also be careful in their discussions with the accused. References to a prosecution can sometimes amount to a charge of extortion. ${ }^{135}$ Section 346 of the Criminal Code $^{136}$ defines extortion as making a threat in order to induce someone to do something without reasonable justification or excuse. An unreasonable threat of prosecution may fit this definition. Before expressing the intent to prosecute the private prosecutor can look to the Ministry guidelines regarding cautions. ${ }^{137}$

\section{Evidence and Proof}

As noted above, the facts that the private prosecutor would need to prove in prosecutions of "failure to comply" offences are not complicated. They would need to prove that an order was made against the accused, that the order was served and that the order was not paid within thirty days. Section 140 of the ESA contains special evidentiary rules for proving the above facts. A certified copy of an order signed by an Employment Standards Officer is proof that the order was made. ${ }^{138}$ Service can be proven by a certificate of service certified by an Officer. ${ }^{139}$ Lastly, the lack of payment can be proven by a certificate of default signed by the director of employment standards. ${ }^{140}$ The ESA specifically states that the Officer does not need to appear in court to attest to these documents.

The worker or legal clinic would already have a copy of the order signed by an Officer. However, they would not have copies of the certificate of service or certificate of default. In the unlikely event that the Ministry refuses to provide these

$131 \mathrm{Ibid}$. at para 22; Rv. Brown, [2002] 2 S.C.R. 185, 2002 SCC 32.

132 Discussions with Ministry staff.

133 R.S.O. 1990, c. F-31.

134 Federal Crown Policy, supra note 127. Although these guidelines are not law, the private prosecutor should be aware of them.

135 Mallet, supra note 60 at 18.

136 Supra note 66.

137 Ministry Procedures Manual, supra note 116 at 7.7.2.

138 ESA, supra note 3, s. 140 (1).

139 Ibid. s. 103 (7).

140 Ibid. s. 140 (3). 
documents, the private prosecutor could subpoena the Officer who investigated the violation and call the worker as a witness. ${ }^{141}$ Alternatively, the private prosecutor could prove the elements of the offence through other evidence because the certificates are a sufficient form of proof but are not necessary. ${ }^{142}$

In many cases the private prosecutor will want to prosecute the directors personally, especially where the offending corporate body is now defunct. A director must have personally failed to pay an order under the ESA in order to be in contravention of the act. Therefore, a director can be prosecuted without consent of the Ministry only if an order has been issued against the director and he or she is in default. However, with consent of the Ministry, any agent of the corporation may be prosecuted for permitting or acquiescing in an offence under the ESA. ${ }^{143}$ This would capture cases where the Ministry failed to issue directors orders or cases where the bad boss is immune from an Officer's order because they are not technically listed as a corporate director. Regardless, the potential private prosecutor should request that the Ministry issue directors orders within the statutory limitation period.

\section{E. Malicious Prosecutions, Abuse of Process and Costs}

Any prosecution can be stayed if it constitutes a malicious prosecution or an abuse of process. A prosecution is malicious if the prosecutor did not have reasonable and probable grounds to believe that the defendant did the alleged act or if the prosecutor acted in malice or for an improper motive. ${ }^{144} \mathrm{~A}$ proceeding is an abuse of process where allowing a trial would violate the fundamental principle of justice through oppressive or vexatious proceedings. ${ }^{145}$ Prosecuting for the purpose of resolving an ongoing civil proceeding or solely to draw public attention to an issue have been considered improper motives in the past. ${ }^{146} \mathrm{Al}$ though they are often without merit, accusations of malicious prosecution and abuse of process are frequently made against private prosecutors. To pre-empt such allegations, a private prosecutor should follow a clear prosecution policy and document the reasons for deciding to prosecute.

Cost awards against a Crown or private prosecutor are very rare under the Provincial Offences Act. ${ }^{147}$ For cost awards to be made there must be a breach of the defendant's Charter ${ }^{148}$ rights, oppressive or improper conduct by the prosecutor, abuse of process, or an irregularity in form (i.e. procedural mistake) that the defendant relies on to his or her detriment. ${ }^{149}$ The private prosecutor can easily avoid costs awards by taking care to press charges for legitimate reasons and by conducting the prosecution according to a reasonable standard of care.

$141 \mathrm{Ibid}$ s. 90 (an Officer is not a compellable witness in a civil proceeding).

142 Ibid. s. 140.

143 Ibid. s. 137.

144 Mallet, supra note 60 at 18.

145 Ibid. at 88.

146 Ibid.

147 Supra note 21; Sheilagh Stewart, Stewart on Provincial Offences Procedure in Ontario (Salt Spring Island, BC: Earlscourt Legal Press Inc, 2005) at 255-260.

148 Canadian Charter of Rights and Freedoms, Part I of the Constitution Act, 1982, being Schedule B to the Canada Act 1982 (U.K.), 1982, c.11.

149 Stewart, supra note 146 at 255-260; See also POA, supra note 21, s. 60, 90, 142. 


\section{F. Proposed Policy}

Legal clinics should have a policy regarding private prosecutions in order to ensure that defendants are treated fairly and to avoid accusations of undue bias, malicious prosecution, or abuse of process. The provincial and federal crown attorney policies state that charges should be laid where there is "reasonable prospect of conviction" and only in accordance with the "public interest." 150 The Ministry of Labour prosecution policy simply states that "the purpose of prosecution is deterrence." 151 Private prosecutions should be instituted where it is in the public interest to do so, based on factors including, but not limited to, deterrence. The rights of the victim and the wrong that has been committed by the accused are also relevant considerations. However, factors such as media and publicity should not be the goal of the private prosecutor because this invites an accusation of improper purpose.

In deciding whether to press charges, the private prosecutor could follow the Ministry policy with a few modifications. ${ }^{152}$ The Ministry policy is discretionary, whereas one should always prosecute in certain circumstances. Based on the Ministry policy, I would suggest that an employer should be prosecuted where,

- the offence is serious (e.g. prolonged failure to pay, reprisals) OR the offender has repeatedly violated similar employment standards; AND

- there is a reasonable prospect of conviction.

The only justification for deviating from this policy would be where the employer is able to establish that he or she is impecunious, was unable to pay when the original violation occurred, and has made good faith efforts to pay. Private prosecutors could protect themselves and avoid unfairness by following this or a similar policy.

\section{CONCLUSION}

This essay has presented an argument for the use of private prosecutions of employment standards violations and has provided a model for how they could be pursued. The prevalence of private prosecutions has waned but their importance has not. When the state fails to protect its citizens - either because they are slow to react to social change or because they are less interested in protecting the disenfranchised - private prosecutions are the last refuge of the victimized. The right to privately lay charges is one of the few democratic checks on the public prosecutor's near absolute discretion. In keeping with its public interest heritage, private prosecutions should be used to ensure that the rights of workers are protected in the face of government failure.

Like many other regulatory regimes, the employment standards regime is

150 Federal Crown Policy, supra note 127; Ontario Crown Policy, supra note 127.

151 Ministry Procedure Manual, supra note 116 at 7.7.1.

152 Ibid. at 7.7.1.2. 
poorly enforced. The vast majority of violators go unpunished and most are not even forced to fully compensate the victim for what is owed. Private prosecutors can help close this enforcement gap. However, even calling the problem an 'enforcement gap' belittles the real life effects of employment standards violations. These violations increase the chances that an abused employee will fall into chronic poverty, homelessness, mental illness or other social ills. As these violations add up, society as a whole suffers. This need not be the case. Many reforms are required, including more proactive investigations, increased fines, faster processes, and redefined legal categories. Prosecutions are just one tool, but they are unique in that they express the fact that violations of employment standards are crimes. They vindicate the rights of often powerless and disenfranchised workers and they are necessary to show that we, as a society, recognise the importance of work to the life, well-being and human dignity of all people.

Appendix A: Steps to a private prosecution under Ontario's Employment Standards Act,2000

\begin{tabular}{|c|c|}
\hline Action & $\underline{\text { Deadline }}$ \\
\hline 1. File an ESA claim & $\begin{array}{l}6 \text { months after the unpaid wages became } \\
\text { due }^{1}\end{array}$ \\
\hline \multicolumn{2}{|l|}{ 2. Attend fact finding, order issued } \\
\hline $\begin{array}{l}\text { 3. Review for appropriateness of prosecu- } \\
\text { tion; if appropriate, request Ministry } \\
\text { prosecution }\end{array}$ & 1 year after order issued \\
\hline $\begin{array}{l}\text { 4. Request orders against corporate direc- } \\
\text { tor by the Ministry }\end{array}$ & $\begin{array}{l}18 \text { months after claim filed (directors } \\
\text { orders can only be issued for } 2 \text { years after } \\
\text { claim filed) }\end{array}$ \\
\hline $\begin{array}{l}\text { 5. Request certificates proving order, } \\
\text { service and non-payment; }{ }^{2} \text { use freedom } \\
\text { of information to request the Officer's } \\
\text { file and the compliance history of the } \\
\text { offender }\end{array}$ & 18 months after order issued \\
\hline $\begin{array}{l}\text { 6. Compile a prosecution brief, includ- } \\
\text { ing a document outlining the reasons to } \\
\text { prosecute }\end{array}$ & 20 months after order issued \\
\hline $\begin{array}{l}\text { 7. Prepare an information; swear the in- } \\
\text { formation before a Justice of the Peace }\end{array}$ & $\begin{array}{l}23 \text { months after the first order is issued } \\
\text { (prosecutions can only be commenced for } \\
2 \text { years after the offence) }\end{array}$ \\
\hline \multicolumn{2}{|l|}{$\begin{array}{l}\text { 8. Serve the summons issued by the Jus- } \\
\text { tice of the Peace }\end{array}$} \\
\hline $\begin{array}{l}\text { 9. Request that the Ministry conduct the } \\
\text { prosecution in cooperation with the pri- } \\
\text { vate prosecutor }\end{array}$ & \\
\hline
\end{tabular}

The Ministry of Labour's procedure manual for Employment Standards Officers is a useful resource for all steps in a private prosecution. ${ }^{153}$

1 See the ESA, supra note 3, for exceptions to this limitation period.

2 See text accompanying footnote 139 .

153 See the Ministry Procedure Manual, supra note 116 at 7.7. 